\title{
Therapeutic Effect of Al-Quran Murattal (Surah Yusuf) on Blood Pressure Level in Pregnant Women with Preeclampsia
}

\author{
Sri Rejeki ${ }^{1}$, Sumastia Trimuliani' ${ }^{1}$, Machmudah Machmudah ${ }^{1}$, Nikmatul Khayati ${ }^{1}$
}

${ }^{1}$ Universitas Muhammadiyah Semarang, Indonesia

\section{Article Info}

\section{Article History: \\ Accepted March 4th, 2020}

\section{Keywords:}

Surah Yusuf murattal therapy; Blood Pressure; pre-eclampsia

\section{INTRODUCTION}

The main complications that cause almost $75 \%$ of maternal deaths are heavy bleeding, infection, high blood pressure during pregnancy (preeclampsia or eclampsia) and complications from unsafe abortion. ${ }^{1}$ Based on the distribution of the causes of maternal mortality, it is known that the cause of maternal death is $30.3 \%$ bleeding, $28.8 \%$ hypertension, $\quad 7.3 \%$ infection, $1.8 \%$ prolonged labour, $1.6 \%$ abortion and $40.8 \%$

\section{Abstract}

Pre-Eclampsia was recorded as a cause of maternal death in Indonesia in 2017, which was 28.8\%. Hypertension is a sign of pre-eclampsia. Murattal Therapy Letter Yusuf is a non-pharmacological therapy that can be used to reduce blood pressure. The purpose of this study is to determine the effect of Murattal Therapy in reducing blood pressure in pregnant women with pre-eclampsia. The design of this study used the Quasy Experiment design with One Group Pretest and Posttest Design. As the population are pregnant women who are diagnosed with pre-eclampsia. 15 respondents were selected using purposive sampling. Data collection tool with an observation sheet and tensimeter. The data collection technique was carried out using the respondent placed in a conditioned room, then listening to the letter of Joseph for 15 minutes using a tape recorder and then his blood pressure was measured. From the 15 respondents after Murotal therapy, the result of a decrease in blood pressure with a statistical test using a paired t-test obtained a p-value of systolic blood pressure of 0,000 and diastolic blood pressure of 0,000 . Murattal therapy can stimulate a controlled autonomic nerve and cause secretion of epinephrine and norepinephrine by the controlled adrenal medulla. Control hormones epinephrine and norepinephrine will inhibit the formation of angiotensin which can reduce blood pressure. Surah Yusuf's Murattal Therapy can reduce the blood pressure of pregnant women with pre-eclampsia.

others. ${ }^{2}$ The causes of maternal death in Central Java are hypertension in pregnancy i.e. $32.97 \%$ (Pre-eclampsia), bleeding $30.37 \%$, circulatory system disorders $12.36 \%$, infections $4.34 \%$, metabolic disorders $0.87 \%$ and others $19.09 \% .^{3}$

Pre-eclampsia is one of the highest causes of maternal death besides bleeding and infection with a significant incidence. Preeclampsia is a collection of symptoms that arise in pregnant and puerperal women

Corresponding author:

Sri Rejeki

srirejeki@unimus.ac.id

South East Asia Nursing Research, Vol 2 No 1, March 2020

ISSN:2685-032X

DOI: https://doi.org/10.26714/seanr.2.1.2020.27-32 
consisting of increased blood pressure, oedema, and proteinuria that appear in pregnancy from 20 weeks until the end of the first week after delivery. ${ }^{4}$

The impact of pre-eclampsia-eclampsia on the fetus can result in low birth weight, impaired placental function, fetal hypoxia, intrauterine growth restriction (IUGR), prematurity, dysmaturity, and IUFD or fetal death in the womb. The impact of preeclampsia-eclampsia on the mother is placental abruption, hypofibrinogenemia, hemolysis, brain haemorrhage, damage to the capillaries of the eye to blindness, pulmonary oedema, liver necrosis, heart damage, HELLP syndrome, kidney disorders. The most severe complication of pre-eclampsia-eclampsia is maternal death. ${ }^{5}$

Al-Qur'an is one method of treatment that has all kinds of programs and data needed to treat various kinds of disorders of the body's cells. Murattal (listening to the reading of the Qur'an) is one of the healing methods using the Qur'an. Listening to the murattal of the Qur'an can affect emotional intelligence (EQ), intellectual intelligence (IQ), as well as one's spiritual intelligence (SQ). Listening to Murattal will have a calming and relaxing effect on a person so that it will also contribute to the reduction in blood pressure. ${ }^{6}$

According to Kartini, the Murattal Alqur'an technique is proven to provide a calm and relaxing effect because it provides a positive perception response which can further stimulate the hypothalamus to release endorphins which are hormones that make a person feel happy so that they can reduce the blood pressure. ${ }^{7}$ Kartini's research is also supported by the results of research from Diki ${ }^{8}$. There is an effect of Murattal Therapy on blood pressure or there is a difference in blood pressure before and after getting the treatment. ${ }^{6}$ The Murattal used in this study was Surah Yusuf. Surah Yusuf consists of 111 verses, where Surah contains the story of the Prophet Joseph.
Surah Yusuf is believed to have virtue as a means (Washilah) to get offspring who have a face and character as beautiful as the Prophet Yusuf. ${ }^{9}$

Based on the above information, the present research deals with the therapies that can reduce blood pressure in pregnant women with pre-eclampsia. The effect of Murattal Surah Yusuf's Therapy was examined on the blood pressure of preeclamptic pregnant women.

\section{METHODS}

\section{Population and sample}

This research is a quantitative study with a Quasy Experiment research design with One Group Pretest and Posttest Design. The population is pre-eclampsia pregnant women who check their contents in the poly content of Rowosari Puskesmas and Kedungmundu Puskesmas. The method of taking samples uses purposive sampling so that the number of samples is 15 respondents. This research was conducted in the working area of Rowosari Community Health Center and Kedungmundu Health Center. Data collection tool with an observation sheet and tensimeter as a blood pressure gauge. The research process takes place from March-April 2019.

\section{Statistic analysis}

Descriptive analysis is performed for all variables. Data were analyzed univariately and bivariate. Bivariate analysis using paired t-test. The statistical significance test is defined by $\mathrm{p} \leq 0.05$. All data were analyzed using SPSS VERSION 17. Values for measurements are presented as mean \pm SD.

\section{RESULTS}

The respondents are with an average age of 34.47 years, most mothers with 3rd pregnancy status were 6 respondents $(40 \%)$ and, the average gestational age was 27 weeks, and there was no risk of 
depression as many as 15 respondents (100\%).

Table 1

The characteristics of respondents by age and gestational age $(n=15)$

\begin{tabular}{lcccc}
\multicolumn{5}{c}{ gestational age $(\mathrm{n}=15)$} \\
\hline Indicators & Min & Max & Mean & SD \\
\hline Age & 27 & 46 & 34.47 & 5.055 \\
\hline Gestational age & 21 & 38 & 27 & 4.405 \\
\hline
\end{tabular}

Based on Table 2 it could be seen the average systolic blood pressure and diastolic blood pressure of respondents on the 1 st, 2 nd and 3rd day before being given Murattal Surah Yusuf Therapy. The mean systolic blood pressure of the respondents before the highest treatment was on the first day of $148 \mathrm{mmHg}$ and the standard deviation was 5.815 with the highest systolic blood pressure of $160 \mathrm{mmHg}$ and the lowest of $140 \mathrm{mmHg}$. The average of systolic blood pressure on the second day was $144 \mathrm{mmHg}$ and the standard deviation was 5.499 with the highest blood pressure of $155 \mathrm{mmHg}$ and the lowest was 140 mmHg. The average diastolic blood pressure of respondents before the highest treatment on day 1 was $95 \mathrm{mmHg}$ and the standard deviation was 4.805 with the highest diastolic blood pressure of 100 $\mathrm{mmHg}$ and the lowest was $90 \mathrm{mmHg}$. The lowest diastolic blood pressure was on the 3rd day of $92 \mathrm{mmHg}$ and the standard deviation was 4.169 with the highest diastolic blood pressure of 100 and the lowest of $90 \mathrm{mmHg}$.

Based on table 2, it can be found that the average systolic blood pressure and diastolic blood pressure of respondents on the 1st, 2nd and 3rd day after being given Murattal Surah Yusuf Therapy. The mean systolic blood pressure of the respondents after treatment on the first day was 136 $\mathrm{mmHg}$ and the standard deviation was 5.815 with the highest systolic blood pressure of $150 \mathrm{mmHg}$ and the lowest was $130 \mathrm{mmHg}$ with the highest diastolic blood pressure of $100 \mathrm{mmHg}$ and lowest of 80 mmHg. The mean systolic blood pressure of the respondents after treatment on the second day was $134 \mathrm{mmHg}$ and the standard deviation was 4.952 with the highest systolic blood pressure of 140 $\mathrm{mmHg}$ and the lowest was $130 \mathrm{mmHg}$ with the highest diastolic blood pressure of 90 $\mathrm{mmHg}$ and lowest of $80 \mathrm{mmHg}$. The average systolic blood pressure of the respondents after treatment on the 3rd day was 134 $\mathrm{mmHg}$ and the standard deviation was 4.419 with the highest systolic blood pressure of $140 \mathrm{mmHg}$ and the lowest was $130 \mathrm{mmHg}$. The average diastolic blood pressure of the respondent after treatment on the 3rd day was $86 \mathrm{mmHg}$ and the standard deviation was 4.499 with the highest diastolic blood pressure of 90 $\mathrm{mmHg}$ and lowest of $80 \mathrm{mmHg}$.

Based on table 2, it can be said that the mean systolic blood pressure from 3 treatments before performing the Murattal Therapy of Surah Yusuf was $145 \mathrm{mmHg}$ with a standard deviation of 4.355 with the highest systolic blood pressure of $153 \mathrm{mmHg}$ and the lowest systolic blood pressure of $140 \mathrm{mmHg}$. The average of diastolic blood pressure before performing Murattal Therapy Surah Yusuf was $93 \mathrm{mmHg}$ with a standard deviation of 3.241 with the highest diastolic blood pressure of $100 \mathrm{mmHg}$ and the lowest diastolic blood pressure of $90 \mathrm{mmHg}$.

Based on table 2, it can be found that the average of systolic blood pressure from 3 treatments after the Murattal Surah Yusuf Therapy was 134 with a standard deviation of 4.024 with the highest systolic blood pressure $143 \mathrm{mmHg}$ and the lowest systolic blood pressure of $130 \mathrm{mmHg}$. The average of diastolic blood pressure after performing Murattal Surah Yusuf Therapy was 86 with a standard deviation of 3.360 with the highest diastolic blood pressure of 93 $\mathrm{mmHg}$ and the lowest diastolic blood pressure of $82 \mathrm{mmHg}$. 
Table 2

Average of blood pressure before and after being given Murattal Surat Yusuf therapy days 1, 2 and 3 (n=15)

\begin{tabular}{lccc}
\hline \multicolumn{1}{c}{ Indicators } & Day 1 & Day 2 & Day 3 \\
\hline Before therapy & & & \\
Systolic, mean (SD) & $148( \pm 5,815)$ & $144( \pm 5,499)$ & $145( \pm 4,577)$ \\
Diastolic, mean (SD) & $95( \pm 4,806)$ & $93( \pm 4,082)$ & $92( \pm 4,169)$ \\
\hline After therapy & $136( \pm 5,815)$ & $134( \pm 4,952)$ & $134( \pm 4,419)$ \\
Systolic, mean (SD) & $86( \pm 6,114)$ & $85( \pm 4,169)$ & $86( \pm 4,499)$ \\
Diastolic, mean (SD) & & & \\
\hline
\end{tabular}

\section{DISCUSSION}

As a result of this study, it was found that the respondents' blood pressure measurements carried out 10 minutes before the Murattal Surah Yusuf Therapy. It was carried out on all respondents experiencing high blood pressure. The highest blood pressure was 153/100 $\mathrm{mmHg}$ and the lowest was $140 / 90 \mathrm{mmHg}$. While the average respondent's blood pressure was 145.67 / $93.80 \mathrm{mmHg}$. An increase in the blood pressure of respondents who were pregnant women with a womb $>2$ weeks of age had a pregnancy-specific syndrome which was mainly related to the lack of organ perfusion due to vasospasm and endothelial activation, which manifests with blood pressure and proteinuria or socalled preeclampsia. ${ }^{8}$

After the respondent was given Murattal Surah Yusuf Therapy treatment, the respondent was remeasured for blood pressure in 10 minutes after the Murattal Surah Yusuf Therapy was performed. The result showed that all respondents $(n=15)$ experienced a decrease in blood pressure either in systolic or diastolic pressure after Murattal Surah Yusuf Therapy. The highest blood pressure became 143/93 $\mathrm{mmHg}$, while the lowest blood pressure was $130 / 82 \mathrm{mmHg}$. The average blood pressure of the respondent became 134.56 / 86.22 mmHg. Listening to the Murattal of the Qur'an gave influence on emotional intelligence, (EQ) intellectual intelligence (IQ), and spiritual intelligence (SQ) of a person. Listening Murattal would cause a calm and relaxing effect on a person so that it would also contribute to reducing the blood pressure, anxiety levels and pain intensity. ${ }^{6}$

The result showed that Murattal Surah Yusuf Therapy influenced blood pressure causing reduction of blood pressure among pregnant women who had pre-eclampsia. The result showed a significant decrease in blood pressure seen from the difference in average blood pressure before and after the Murattal Surah Yusuf Therapy for 15 minutes, which amounted to $11.104 \mathrm{mmHg}$ at systolic pressure and $7.578 \mathrm{mmHg}$ at diastolic pressure. A paired $t$-test of systolic pressure obtained $p$-value $=0.000$. While the test on the paired diastolic pressure $t$-test resulted in $p$-value $=0.000$, Ha was accepted, and Ho was rejected, and it meant that there was an influence of Murattal Surah Yusuf Therapy in the blood pressure of pregnant women with pre-eclampsia at Community Health Center of Rowosari and Kedungmundu.

Based on these results, it could be concluded that Murattal Surah Yusuf Therapy could reduce the blood pressure in pregnant women who got pre-eclampsia. The positive perception obtained from the Murattal Al-Quran would stimulate the hypothalamus to release endorphins, as we know that this hormone would make someone feel happy. Furthermore, the amygdala would stimulate the activation and control of the autonomic nerve which consists of the sympathetic and parasympathetic nerves. The parasympathetic nerves are connected to the heart, and it made the heart work slowly. Meanwhile, parasympathetic nerves played vice versa role. Controlled autonomic nerve stimulation would cause 
epinephrine secretion and norepinephrine by the adrenal medulla. Controlled by epinephrine hormone and norepinephrine would inhibit the formation of angiotensin which could further reduce the blood pressure. ${ }^{9}$

Before giving Murattal Surah Yusuf Therapy, the blood pressure of all respondents was mean of 145.67 / 93.80 mmHg with the highest blood pressure of $153 / 100 \mathrm{mmHg}$ and the lowest of 140/90 mmHg. After the respondent was given treatment, the result showed that all respondents $(n=15)$ experienced a decrease, the highest blood pressure being $143 / 93 \mathrm{mmHg}$ and the lowest was 130/82 $\mathrm{mmHg}$. So, the average blood pressure of the respondent becomes 134.56 / $86.22 \mathrm{mmHg}$. Surah Yusuf murattal therapy is effective in lowering the blood pressure of pregnant women who got pre-eclampsia both in the case of systolic blood pressure $(p=0.000)$ and diastolic blood pressure $(p=0.000)$.

The nurses are expected to apply Murattal Surah Yusuf Therapy in providing comprehensive and holistic nursing care to pregnant women who got pre-eclampsia. The recommendation for nursing education is expected to be one of the treatment discussions to reduce blood pressure in preeclampsia pregnant women in counselling activities to the wider community. It is expected that future research should be carried out by considering the adequacy of the research sample and can also by comparing other therapies such as SEFT, Acupuncture or Acupressure Therapy.

\section{CONCLUSION}

The nurses are expected to apply Murattal Surah Yusuf Therapy in providing comprehensive and holistic nursing care to pregnant women who got pre-eclampsia. The recommendation for nursing education is expected to be one of the treatment discussions to reduce blood pressure in preeclampsia pregnant women in counselling activities to the wider community. It is expected that future research should be carried out by considering the adequacy of the research sample and can also by comparing other therapies such as SEFT, Acupuncture or Acupressure Therapy.

\section{ACKNOWLEDGMENTS}

We would like to express our appreciation to all patients who participated in this study and to the heads and nurses of Rowosasi and Kedung Mundu puskesmas who provided valuable assistance during data collection.

\section{CONFLICTS OF INTEREST}

Neither of the authors has any conflicts of interest that would bias the findings presented here.

\section{REFERENCES}

1. World Health Organization. Maternal Mortality. [accessed 6 March 2020]. Available at: https://www.who.int/en/news-room/factsheets/detail/maternal-mortality

2. Kementerian Kesehatan Republik Indonesia. 2015 Profil Kesehatan Indonesia. [accessed 6 March 2020]. Available at: https://www.kemkes.go.id/resources/downloa $\mathrm{d} /$ pusdatin/profil-kesehatan-indonesia/profilkesehatan-Indonesia-2015.pdf

3. Dinas Kesehatan Kota Semarang. Profil Kesehatan Kota Semarang Tahun 2017. [accessed 6 March 2020]. Available at: https://dinkes.semarangkota.go.id/asset/uploa d/Profil/Profil/Profil\%20Kesehatan\%202017.p df

4. Sukarni I. Patologi: Kehamilan, Persalinan, Nifas dan Neonatus Resiko Tinggi. Yogyakarta: Nuha Medika; 2014.

5. Kurniasari D, Arifandini F. Hubungan Usia, Paritas Dan Diabetes Mellitus Pada Kehamilan Dengan Kejadian Preeklamsia Pada Ibu Hamil Di Wilayah Kerja Puskesmas Rumbia Kabupaten Lampung Tengah Tahun 2014. Jurnal Kesehatan Holistik. 2015;9(3):142-150.

6. Yuliani DR. Terapi Murattal sebagai Upaya Menurunkan Kecemasan dan Tekanan Darah pada Ibu Hamil dengan Preeklampsia: Literature Review Dilengkapi Studi Kasus. Jurnal Kebidanan. 2018;8(2):79-98. 
7. Kartini K, Fratidhina Y, Kurniyati H. Pengaruh mendengarkan murattal terhadap penurunan tekanan darah pada ibu hamil preeklamsi di RSIA PKU Muhammadiyah tangerang. Jurnal JKFT. 2016;2(2):40-47.
8. Lalenoh DC. Preeklampsia Berat dan Eklampsia: Tatalaksana Anastesia Peioperatif. Yogyakarta: Deepublish: 2018.

9. Erlina E, Raharjo SB. Terapi Murattal Ar-Rahman Terhadap Perubahan Tekanan Darah Pasien Hipertensi Di Rsudza Banda Aceh. Bandung: RuangKata Imprint Kawan Pustaka: 2016. 